\title{
Bentham, Deleuze and Beyond: An Overview of Surveillance Theories from the Panopticon to Participation
}

\author{
Maša Galič $^{1} \cdot$ Tjerk Timan $^{1} \cdot$ Bert-Jaap Koops $^{1}$
}

Received: 30 October 2015 / Accepted: 18 April 2016/Published online: 13 May 2016

(C) The Author(s) 2016. This article is published with open access at Springerlink.com

\begin{abstract}
This paper aims to provide an overview of surveillance theories and concepts that can help to understand and debate surveillance in its many forms. As scholars from an increasingly wide range of disciplines are discussing surveillance, this literature review can offer much-needed common ground for the debate. We structure surveillance theory in three roughly chronological/thematic phases. The first two conceptualise surveillance through comprehensive theoretical frameworks which are elaborated in the third phase. The first phase, featuring Bentham and Foucault, offers architectural theories of surveillance, where surveillance is often physical and spatial, involving centralised mechanisms of watching over subjects. Panoptic structures function as architectures of power, not only directly but also through (self-) disciplining of the watched subjects. The second phase offers infrastructural theories of surveillance, where surveillance is networked and relies primarily on digital rather than physical technologies. It involves distributed forms of watching over people, with increasing distance to the watched and often dealing with data doubles rather than physical persons. Deleuze, Haggerty and Ericson, and Zuboff develop different theoretical frameworks than panopticism to conceptualise the power play involved in networked surveillance. The third phase of scholarship refines, combines or extends the main conceptual frameworks developed earlier. Surveillance theory branches out to conceptualise surveillance through concepts such as dataveillance, access control, social sorting, peer-to-peer surveillance and resistance. With the datafication of society, surveillance combines the physical with the digital, government with corporate surveillance and top-down with self-surveillance.
\end{abstract}

Keywords Surveillance theory - Discipline - Control · Surveillant assemblage . Surveillance capitalism $\cdot$ Participatory surveillance

Tjerk Timan

t.timan@uvt.nl; http://www.uvt.nl/tilt/

1 Tilburg Institute for Law, Technology, and Society - TILT, Tilburg University, PO Box 90153, 5000 LE Tilburg, The Netherlands 


\section{Introduction}

Surveillance is a topical issue in Western societies, with growing awareness and an increase in both number and type of surveillance technologies. Throughout the second half of the previous century, not only the type and number of surveillance technologies but also the type and scope of persons and spaces being surveilled have gradually increased. This has triggered the emergence of a scholarly discipline called surveillance studies, a multidisciplinary field covering both theoretical and empirical accounts of past, current and near-future surveillance in society. However, since surveillance is used as an umbrella term that covers a broad range of sub-topics discussed in other domains as well (e.g. privacy, urban planning, governance, policing, safety and security), the concept of surveillance features increasingly in different contexts and disciplines, making it harder to follow and focus debates across disciplines. Therefore, the aim of this paper is to provide a largely chronological-thematic overview of surveillance theories and concepts that can help scholars from an increasingly wide range of disciplines to understand and debate surveillance in its many forms.

The term surveillance can be deconstructed in its etymological parts 'sur' (from above), and 'veillance' (to watch). Where often first associations with the terms surveillance are that of Closed-Circuit Television (CCTV) cameras placed in city centres and other spaces (e.g. airports, highways, the workplace), the term has been discussed before the emergence of ubiquitous electronic eyes in public (and, increasingly, private) spaces. Due to vast and seemingly radical technological changes that information and communication technologies (ICTs) have brought about since roughly the 1960s, the term surveillance has been spreading both in meaning and substance and has been theorised from a large range of disciplines. One point of departure for understanding surveillance can be found in Lyon's explanation of surveillance being about both caring and controlling (Lyon 2006). The subject of surveillance is being watched with a certain purpose, which can be controlling and disciplining the subject into certain behaviour or a set of norms, but also - possibly at the same time - protecting and caring for that subject. Where this understanding resonates with earlier writings on surveillance, in more recent theories and concepts, the notion of the subject as a passive actor is being questioned, as is the idea of an underlying project to impose certain morals.

In this paper, we will address key theoretical concepts of surveillance (studies), in an attempt to map thematically, and largely chronologically, different ways of thinking about surveillance in society (or surveillance societies), thereby also trying to clarify what surveillance means. Whilst many theoretical and empirical accounts have been added to the body of surveillance literature since Lyon (2001, 2003, 2006, 2007), in our view, a succinct overview of key surveillance theories and concepts is lacking. Therefore, this paper offers a literature review of the main surveillance theories and thinkers. We structure the paper by distinguishing certain clusters of scholars and discussing authors and theories on the basis of associated content and concepts. These clusters can roughly be ordered chronologically by distinguishing the following three phases in surveillance theory building.

(1) Bentham's liberal project connected to the architectural design of a prison and other buildings and Foucault's subsequent analysis of discipline and the Panopticon as a metaphor to talk about institutions and society. This has laid the foundations of surveillance theory in the form of a conceptual framework that still resonates today. 
(2) Post-Panoptical theories of surveillance. The second phase moves away from the Panopticon to develop alternative theoretical frameworks for capturing surveillance. Here, we will focus on Deleuze's (and Guattari's) control societies, linked to bureaucracy and the dawn of a computerised, networked society, followed by Haggerty and Ericson's surveillant assemblage and Zuboff's surveillance capitalism.

(3) Contemporary conceptualisations of surveillance. Rather than developing new or alternative comprehensive theoretical frameworks, much of contemporary surveillance theory is characterised by refinements of, and additions to, the main conceptual frameworks developed earlier. Surveillance theory branches out in different directions, from new types of Panopticons and digital surveillance to more user-centric perspectives of participation and resistance.

\section{Phase 1: Exploring the Panopticon}

\subsection{Bentham's Panopticons: The Limited Reach of the Spatial Panoptic Gaze}

The Panopticon is probably Bentham's best-known but also most controversial idea (Schofield 2009). It has become the most widely used metaphor for surveillance, becoming almost its synonym. The Panopticon has become particularly famous through Foucault's concept of panopticism, resulting in Bentham often being understood through the reading of Foucault. This, however, is misleading, and scholars are beginning to advocate that Bentham's thought be re-examined and the boundaries of wellestablished Foucauldian 'truths' about the Panopticon (which will be further reexamined in section 2.2) be pushed back (Brunon-Ernst and Tusseau 2013). In fact, scholarship has relatively recently come to the conclusion that Bentham did not create one Panopticon but at least four Panopticons. ${ }^{1}$ Besides, the well-known 'prisonPanopticon' (described primarily in Panopticon; or the Inspection-House (1786, 1790-1791)), there are also the 'pauper-Panopticon' (designed for the housing of indigents but also for reformation and work; described primarily in Outline of a Work entitled Pauper Management Improved (1797-1798)), the 'chrestomatic-Panopticon' (a Panopticon-shaped day-school, where one inspecting master could supervise pupils without being seen; described primarily in Chrestomathia (1816-1817)) and the 'constitutional-Panopticon' (although the term Panopticon is not used, the architectural arrangements are panoptic; described primarily in Constitutional Code (1830)). Foucault's concept of panopticism is primarily grounded on Bentham's description of the prison-Panopticon. However, the three less-known Panopticons do more than merely replicate the original prison-Panopticon idea; they present amended versions of the idea, reflecting its adaptation to new contexts and exemplifying different panoptic and even anti-panoptic features. Thus, Bentham uses 'the Panopticon' as a paradigmatic idea that can be adapted and used in a variety of social spaces and for different purposes.

The prison-Panopticon depicts a prison designed as a circular building (Bentham later amended its shape to an octangular shape, whilst the pauper-Panopticon was dodecagonal), with an inspector in the central tower who oversees the activities of

\footnotetext{
${ }^{1}$ Classification by Anne Brunon-Ernst, Deconstructing Panopticism into the Plural Panopticons, in Beyond Foucault (2013).
} 
convicts in their cells. It is essentially an architectural idea, a 'strategy of space', but one that results in a 'new mode of obtaining power of mind over mind in a quantity hitherto without example' (Bentham 2010, 15). Through specific architectural design, an illusion of constant surveillance is created - the prisoners are not really watched constantly but they believe they are. In Bentham's time, possibilities of surveillance were significantly bound by physical limitations. One of the key ideas or effects of the prison-Panopticon (and similarly designed Panopticons) was to create an extension of perception beyond visible locales and the reduction of temporal relations to spatial relations, thus enhancing the possibility of the disciplinary panoptic power (Božovič 2010). Surveillance is carried out from one single point, and it is the inspector in his central lodge who possesses this extended power. The inspector is perceived as an invisible omnipresence, 'an utterly dark spot' (Božovič 2010, 11) in the all-transparent space of the prison-Panopticon, where the inmates are seen without seeing the one who sees them. It is precisely the inspector's apparent omnipresence that sustains perfect discipline in the prison-Panopticon - even a momentary exposure to the eyes of the prisoners would destroy the idea of his omnipresence in the minds of the prisoners. In the prisoners' perception, the inspector is all-seeing, omniscient and omnipotent.

This description of the prison-Panopticon is in line with Foucault's concept of panopticism, which theorises surveillance as involving an all-seeing inspector. Foucault defines panopticism as 'a type of power that is applied to individuals in the form of continuous individual supervision, in the form of control, punishment, and compensation, and in the form of correction, that is, the modelling and transforming of individuals in terms of certain norms' (Foucault 2002, 70) where 'panoptic' refers to 'seeing everything, everyone, all the time' (Foucault 2006, 52). But Bentham's vision, already in the prisonPanopticon, was not to create a 'society of control' where people would be watched all the time; rather, the idea was that discipline would be internalised and the need for the inspector, the watching itself, would be eventually exhausted. This means that truly continuous and all-seeing inspection is not desired at all; in fact, already Bentham's prison-Panopticon was not actually all-seeing, and the purpose of such central inspection was to obviate the need for watching, punishment and the Panopticon itself.

Bentham imagined the Panopticons as liberal political projects-they were proposed solutions to increasing social and economic problems of the time in Britain (e.g. the number of convicts and indigents that was rising fast beyond the state's capabilities, Schofield 2009). According to his utilitarian philosophy, trying to achieve 'the greatest happiness for the greatest number of people', Bentham saw punishment as evil in itself, allowed only if it excluded greater evil. In regard to the prison-Panopticon, the specific architecture thus also served the goal of prisoners' liberation from more overtly coercive forms of institutional violence, which were common at the time. Moreover:

the key point was not the fact that the inmates of Panopticon would be watched all the time, but ... that they would be aware that they might be being watched. The inspector saw an infraction. He did not punish immediately, but waited. He saw a second infraction. At some point thereafter, he would confront the perpetrator with his record book. "See here, your infractions, with the date and time. This is your punishment." Once a punishment had been administered, and the prisoners saw that, should they misbehave, punishment was certain, they would 
no longer misbehave. There would no longer be any need for them to be watched.

They would be reformed. (Schofield 2009, 92)

There is more to Bentham's 'panoptic paradigm' (a term coined by Anne BrunonErnst), than the authoritarian aspects of panoptic power described by Foucault. ${ }^{2}$ The panoptic paradigm as a whole, in the development of Bentham's philosophical and political thought, shows that the Panopticon is a more diverse and reversible structure than Foucault acknowledged. The Panopticon should be seen as a template, which can and should be adapted to the specific circumstances of other parts of society, in which methods of control are more complicated and accompanied by increasing exceptions to continuous individual supervision. In order to show how Foucault's panopticism fits less with Bentham's other Panopticons, the three less-known types will briefly be examined in the following paragraphs.

In the pauper-Panopticon, chronologically the second Panopticon and the most similar to the prison-Panopticon, specific circumstances demanded different treatment, leading Bentham to devise modifications to the building and management rules. The variety within the pauper population, consisting of all ages and coming from a wide variety of backgrounds and occupations, required a much greater degree of discrimination in treatment. Moreover, whilst prisoners were convicted criminals sent to jail by judges and magistrates, the paupers entering the pauper-Panopticon ('the industry house') did so voluntarily. Consequently, most paupers could leave the pauperPanopticon whenever they wanted (although no one would enter a pauperPanopticon unless compelled by circumstances). However, according to the 'earn-first principle', no pauper would be fed and could not leave the Panopticon until he had completed his share of work (Schofield 2009). Also, children that were left in the pauper-Panopticon to be taken care of could not leave until they turned 17 (for girls) or 19 (for boys). ${ }^{3}$ On the other hand, certain groups of paupers were entitled to some privacy on certain occasions, by means of blinds that could be drawn across divisions (e.g. for marital sex, or seeking advice in certain situations from the 'Guardian Elders' - the old paupers, supposedly immune to corruption, who constituted a type of additional 'inspectors' present in the paupers' rooms, Schofield 2009). Nevertheless, the pauper-Panopticon still fits Foucault's panopticism well-enough. In fact, due to specific circumstances demanding different treatment, the pauper-Panopticon involved more complex methods of control in some respects than the prison-Panopticon, such as surveillance done by the Guardian Elders and through book-keeping and rules on feeding and heating.

The third and fourth Panopticons have fewer panoptic and even anti-panoptic features. The use of panoptic devices here is in fact less clear than with the first two. The chrestomatic-Panopticon was a Panopticon-shaped school, where one inspecting

\footnotetext{
2 There are traditionally two schools of thought in Bentham studies: the authoritarian, which sees Bentham as the master mind of authoritarian state control, and the liberal, which sees him as thinking in terms of rule of law, aiming to promote civil and political rights. There is a deep-seated contradiction in Bentham's writings; Anne Brunon-Ernst, Introduction, in Beyond Foucault (2013), pp. 1-2; Schofield (2009), p. 71.

3 The idea was that they needed to "earn back" the money spent for their upkeep, since the pauper-Panopticon, as all Panopticons, needed to be financially viable to serve as a solution to the social and economic problems of the time. Financial viability was a key challenge especially for the pauper-Panopticon and supposedly a key reason for Bentham ultimately to discard the idea of the pauper-Panopticon.
} 
master could supervise around 600 pupils per room without being seen. The plan was based on Bentham's 'scholar-teacher principle', whereby the more advanced pupils taught the less advanced, 'for the greatest improvement of the minds of students and the pockets of their parents' (Brunon-Ernst 2013a, 21-23). Limits to panoptic control are more obvious here: First, panoptic control is exercised only whilst the children are in school; outside, they are out of reach of the panoptic gaze. Second, children were not assigned to a fixed class structure - they could change categories and classes in accordance with their age, subjects and level of achievement. Thus, specific forms of panoptic control upon them can also change.

Panoptic features are least obvious in the constitutional-Panopticon, devised only 2 years before Bentham's death. First, it is no longer the few watching the many but the many watching the few; citizens watch the governors (i.e. all those governing the citizens). The 'panoptic inspection principle' is thereby reversed, which is why certain scholars call this form of the Panopticon the reversed or inverted Panopticon (Semple 1987; Leroy 2002). ${ }^{4}$ The focus is on governing functionaries, who are monitored through the use of more or less panoptic methods, to ensure they act in a way to maximise pleasure and minimise pain, or in other words, to prevent misrule. Second, as in the chrestomatic-Panopticon, the concept of constant visibility does not apply - the governors are monitored only in the course of their public duties, and they can withdraw from the citizens' gaze when they want to rest or enjoy some privacy. The term Panopticon itself is not used in the Constitutional Code; nonetheless, the architectural arrangements are panoptic. The position of the prime minister is at the centre of an oval-shaped building. Communication between the prime minister and his ministers, as well as between ministers themselves, is carried out (as in the other Panopticons) through communication tubes. Furthermore, each ministerial office is a thirteen-sided polygon, with a public or private waiting room on each side for people coming to visit the ministers. Although certain architectural designs remain in the constitutional-Panopticon, the central inspection tower disappears as artefact and as metaphor. Bentham believed that many places become monitored because the people ensure good behaviour on part of their rulers through the instrument of publicity (transparency) (Schofield 2009). In this, the newspaper has a key role, delivering information concerning misrule amongst the people and examining and criticising misrule (Kaino 2008). Inspection (surveillance) is thus no longer central but rather dispersed. In Bentham's thought, the panoptic physical building, initially used strategically as a local architectural device, thus later becomes a universal monitoring tool in the wider project of ensuring good government.

It is primarily with the chrestomatic- and the constitutional-Panopticon that social control moves beyond the margins of society and focuses on its 'heart and head: middle-class children and members of the government' (Brunon-Ernst, 27-28). The prison- and pauper-Panopticon could only reach the people inside the physical buildings with its panoptic control methods; people outside could only be reached with traditional, non-panoptic methods (using language and law, including deterring function). Non-marginalised people, thus, were beyond the panoptic gaze. Have the panoptic characteristics, then, increased rather than decreased in the last two Panopticons,

\footnotetext{
${ }^{4}$ Another example is Umberto Eco's pastiche of the Anopticon, a hexagonal building that effectuates 'the principle of 'being able to be seen by everyone without seeing anyone.' The Anopticon's subject is a prison guard who lives in a closed, central hexagonal room, unable to see anything other than a small circular portion of sky, and who is observed by the prisoners freely walking around in the corridors surrounding the guard's room (from Bert-Jaap Koops, Law, Technology, and Shifting Power Relations, 2010, p. 1035).
} 
which allow a wider gaze? That is not the case. Although the gaze embraced a much wider audience, it came with intentional limitations upon its panoptic power-it was not continuous and all-seeing. In the chrestomatic- and constitutional-Panopticon, the concept of constant visibility is reduced considerably: children were observed only whilst in school and the governors only when performing their public duties. Furthermore, in the constitutional-Panopticon, the gaze is reversed to oversee the rulers. Also, this is no longer done solely through architectural design but through dissemination of information in newspapers, as well. Of course, the news is still dependent on the architecture of the parliamentary building that enables the people to see what the government is doing. Here, the act of watching is no longer described in sinister terms such as central inspection, but in positive ones such as transparency and publicity. These distinct features, some panoptic and others not, characterise what Brunon-Ernst terms Bentham's panoptic paradigm. The panoptic paradigm refers to Bentham's architectural projects operating as a model for governing the behaviour of individuals and groups and the operations of social practices or institutions and having the potential to function in non-disciplinary environments. This feature disqualifies the Panopticon as a uniquely disciplinary (in the Foucauldian sense) machine, since the Panopticons, rather than towards disciplinary power through architectural design, evolved more towards Foucault's concept of governmentality (Brunon-Ernst 2013b, 36), a type of power - initially called sécurité - different from discipline in that it no longer seeks to manage individual bodies but rather manages whole populations, trying to optimally regulate social behaviour. ${ }^{5}$ Bentham's Panopticons are devised in such a way that eventually no more Panopticons will be needed, and the panoptic age should be seen only as a stage in the transition to a non-panoptic utilitarian era, where misrule is minimised and pleasure maximised.

\subsection{Foucault's Panopticism and Disciplinary Societies}

The richness and variation within Bentham's panoptic paradigm has been largely overlooked in surveillance studies. This is because the Panopticon is mainly understood through Foucault's analysis and use of the concept. It is relevant to look into why Foucault's analysis of the Panopticon resonated in so many disciplines, for his analysis is not only rehabilitating (specific parts of) Bentham's work, but also building upon and extending it into a broader perspective on power relations and networks in modern societies.

In analysing the Panopticon, Foucault drew exclusively on Bentham's prison design. He used the architecture and idea of the prison-Panopticon as a diagram, projecting it onto other parts of society to analyse power relations and models of governing (Foucault 1991a). Being a historian, Foucault in Discipline and Punish: The Birth of the Prison explains that since the eighteenth and nineteenth centuries, Western societies can be defined by a new form of power that is capillary and affects 'the grain of individuals, touches their bodies and inserts itself into their actions and attitudes, their discourses, learning processes and everyday lives'

\footnotetext{
${ }^{5}$ The concept of governmentality refers to the shift from the ad hoc governing of nature by the flow of nature (famine, diseases etc.) to a more predictive and number-based, statistical approach through the calculation of events and their impact on the population. For more on governmentality see Foucault, Security, Territory, Population: Lectures at the College de France 1977-1978 (2007); Foucault, The Foucault Effect: Studies in Governmentality (1991); Andrew Dilts and Bernard E. Harcourt, Discipline, Security, and Beyond: A Brief Introduction (2008).
} 
(Foucault 1980, 39). In simpler terms, the Panopticon penitentiary system of governing has become present and active in many or most aspects of Western societies. Yet, and this is what Foucault tries to show through compelling examples, these systems often remain hidden or unnoticed, precisely because they are found in the fibres of daily life, which is what makes them so powerful and ubiquitous.

Through an analysis of different institutions, such as the school, the military, the hospital and the factory, processes of action in daily life have been invaded with Panoptical mechanisms of watching and being watched and, consequently, of disciplining power. When everybody can potentially be under surveillance, people will internalise control, morals and values - discipline is thus a type of power, a strategy and a kind of technology. Accordingly, Foucault coined this type of society the disciplinary-or discipline - society, which (in the West) has seen a development towards technocratic approaches to governing. Foucault's study of power consisted of formal and evident institutions, where the Panopticon was introduced as an 'ideal' system to discipline the individual. Why was this so evocative? Foucault shifted the perspective from the goal of governing to the mode of governing. The main goal is (still) to prosper as a society, delineated by geography or nation state. The mode of governance, however, shifts from a sovereign society (Foucault understood sovereign practices as seeking mainly to affirm control over a territory and secure the loyalty of subjects, in a somewhat static and rigid manner through binary prohibitions, see Valverde 2008) to one of discipline, which represents a shift in method as well as in object, from populations to individuals.

In feudal and later sovereign societies, the question of power is linked to questions of how to organise a population and its land to ensure continuity. By learning from previous years about crop income, for example, or the spread of famine or disease, a sovereign can learn and predict, either to invest in food reserves or trade more crop with neighbouring states, or to control disease by disallowing citizens to travel, whereby early forms of predictive modelling were used to rule the state (Foucault 2007). Statistics, after all, means numbers of the state. A key difference between modern Western societies that Foucault characterises as disciplinary and sovereign societies lies in the type of power at work. In the sovereign society, the sovereign is the one key decider and holder of power and (s)he is known and 'visible' in terms of power signals, such as 'by decree of the King'. In the disciplinary society, power is dispersed and hidden in processes of conformity present in different places of society. Because of these characteristics, discipline is not an exclusive machinery of the State; rather, it moves across different institutions, it links and prolongs them, making them converge and function in a new way (Deleuze 2006). Although this power operates somewhat independently from the judicial and government apparatus, it nevertheless requires institutions and the state, since it works through them - 'the state, correctional institutions, and medical institutions [need to] be regarded as coagulations of practices' (Valverde 2008, 18).

Foucault explains that a phenomenon closely linked and resulting from the disciplining process, is normation. By this, he means the processes that force and create habits, rituals and how things are done, thereby creating norms of behaviour. ${ }^{6}$ In normation processes,

\footnotetext{
6 'The perpetual penalty that traverses all points and supervises every instant in the disciplinary institutions, compares, differentiates, hierarchizes, homogenizes, excludes. In short, it normalizes.' In Foucault, Discipline and Punish (1991), p. 183 (emphasis in original). See also Foucault, Security, Territory, Population - lectures at the college de France, 1977-1978 (2007), pp. 57, where he explains the difference between normation and normalisation.
} 
the norm is central. It constitutes what one has to conform to and strive for; it is both standard and ideal. Being regarded as normal is to conform to the norm, hence to occupy the position of the invisible, i.e. unmarked by difference construed as abnormality, and putative universal subject. The abnormal is the one deemed deficient and inferior in relation to the norm(al) (Dalibert 2013). This is specifically linked to the individual body, as Foucault argues that disciplining the individual body is a governmental utopia, where discipline produces subjected and practiced, 'docile' bodies (Foucault 1991b). As the body is subjected to discipline, it is ordered, subjected to normation. In Foucault's understanding, normation is intrinsic to mechanisms disciplining the body, in which technologies are central (Foucault 2007, referred to in Dalibert 2013, 69).

The process of individualisation in disciplinary societies is what Foucault called descending, as opposed to ascending, in feudal or sovereign societies (Foucault 1980). He explains that in the latter, the overall status of a society, e.g. its total production or health, was an aggregated, collective rather than an individual concern, thereby leaving room for individuals to diversify and develop within the parameters of collective ideals. In contrast, in disciplinary societies, processes of administration focus on individual rather than aggregated actions, rituals and habits, leading to a de-diversification of individual behaviour. Through the shifting focus, individuals are continuously measured against the norm; they become fictional, representative, as they have to be registered and held against a fictional norm. The sovereign power as the key decider and holder of power becomes less visible, and power structures are relocated and replaced by different institutions (schools, hospitals, etc.) in which behaviour is being watched.

Foucault continues that one method and a key indicator of disciplinary societies is found in many institutions that uphold and apply the norm: the exam. The exam incorporates the power of discipline because it tests according to a 'scientific' method the suitability of individuals against a norm. Through different methods of bureaucracy and sequences of how to do things, bodies get disciplined. For instance, the army applies extensive training and testing on using guns, hospitals on procedures of treatment and schools on writing and handling a pen correctly. The product or goal of these disciplining methods is to create docile bodies. This makes for even more predictive and plannable societies in which docile bodies have become units of information, not communication. Here, the link becomes clear with Bentham's prison architecture: it is a one-way street in which individuals are mouldable and remouldable. ${ }^{7}$ Modernity then, in the form of disciplinary societies, is formed by the advent of scientific methods of registration, record-keeping and normation through exams. Docile individuals are no longer governed as actors with whom they communicate, but as units of information that can be moulded. Surveillance is a key concept here because this moulding and re-shaping is a result of the visibility of individuals' 'competencies' through exams and record-keeping of their progress. Foucault briefly mentions, but does not elaborate upon, resistance to disciplining power, by stating that the entanglements of power also give rise to scattered points of resistance that have no cause but power itself, which they resist (Foucault 1998).

The above leads to a way of thinking and applying the concept of the Panopticon as a metaphor to describe a phenomenon that has been coined panopticism. Specifically in

\footnotetext{
7 'The Panopticon was also a laboratory; it could be used as a machine to carry out experiments to alter behaviour, to train and correct individuals.' From Foucault, Discipline and Punish (1991), p. 203.
} 
relation to the rise of CCTV cameras, Foucault's analysis of a methodical and objective observer holding disciplining power resonated very well. Indeed, the watcher cannot be seen, and there is a constant (mediated) gaze that, like the watcher in the watchtower, might see everything. Normation and internalisation of 'doing good' are achieved through cameras, and citizens in public space can thus be moulded into behaving according to the norm. The footage can be stored, allowing the watcher to be 'omnipresent' not only in space, as in Bentham's prison design, but also in time. CCTV seemed the perfect example to prove Foucault's analysis being spot-on, which might help explain the wide resonance of his theory.

However, there are features of CCTV and other forms of electronic surveillance for which the Panoptical model cannot account, simply because under the influence of ICT, society and its institutions have changed radically from those in Foucault's analysis. Foucault already laid the basis for going beyond the disciplinary society by discussing control societies that would be the result of new technologies and their connected methods of surveillance. Control societies continue the de-individualisation that Foucault sketched but evolve into de-humanisation. What this means is that, whilst the infrastructures of discipline in schools and hospitals are normative and shaping behaviour, they still involve a recognition of individuals as human subjects via the representative norm in particular settings; in contrast, in a control society, individuals are not targeted directly as human subjects, but rather through representations. The system of power lies less with foundational and formal institutions and more with ad hoc and informal networks; it works via representations that communicate and decide internally. As a result, control societies not only exercise a different method of governing and as such form a fault-line in thinking about surveillance and the types of societies that surveillance creates. In the following section, we will discuss post-Panoptical concepts that try to deal with this shift towards electronic forms of surveillance and the kind of societies these produce.

\section{Phase 2: Post-Panoptical Theories and Concepts}

The predominance of the panoptical approach to surveillance has led surveillance scholars to advocate discarding the Panopticon when theorizing surveillance today (e.g. Haggerty 2006; Murakami Wood 2007; Lyon 2008). This section features authors who try to develop alternative theoretical frameworks to the Panopticon as the primary model to conceptualise surveillance in modern Western societies. Deleuze, although closely connected to Foucault, ${ }^{8}$ takes a fundamentally different direction in thinking about how and where discipline and control can be found and analysed. They share with Haggerty and Ericson an attempt to find other places of analysis. Deleuze and Guattari locate new places of surveillance in a physically and technologically changed environment, whilst Haggerty and Ericson look particularly at new combinations of humans and technology that exercise forms of surveillance. In a neo-Marxist strand of surveillance theory, Zuboff sketches the contours of another theoretical framework,

\footnotetext{
${ }^{8}$ Foucault and Deleuze took part in many public debates together and published several works together, including Deleuze and Foucault, Les Intellectuels et le Pouvoir (1972), L'Arc, 49, 3-10. Deleuze also wrote extensively about Foucault's ideas, see Deleuze, Foucault (2006); Deleuze, Désir et plaisir (Deleuze 1994), English translation available at: http://www.artdes.monash.edu.au/globe/delfou.html (accessed 02 April 2016).
} 
surveillance capitalism, analysing how surveillance changes power structures in the information economy. These authors thus challenge the units of analysis in the works of Bentham and Foucault, arguing that new analytical tools are needed, and they therewith establish a post-Panoptic stream of surveillance theory.

\subsection{Deleuze's Control Society: From Governments to Companies}

A team of post-structuralist thinkers responded to, and partly built on, Foucault, stating that the objects of study today require a different analysis, now the power dynamics between institutions and individuals are no longer so delineated as they were in Foucault's analysis. Deleuze observed that Foucauldian institutions and their ways of disciplining no longer existed, or at least were shifting into other modes of surveillance and exercising power. Deleuze, partly in collaboration with Guattari, further developed the shift, already described to some extent by Foucault, from disciplinary societies towards societies of control (Deleuze and Guattari 1987; Deleuze 1992). Although the Panopticon is not explicitly discussed nor dismissed, these authors diverge from Panoptical thinking by instead proposing a series of new places of power to conclude that the socio-technical landscape has changed. Especially in the short but high-impact piece 'Postscript on the Societies of Control', Deleuze specifically dismisses the idea of discipline as a goal or driving force of 'governing'; rather, it has to be found in forms of control.

Deleuze considers how the driving forces of capitalism and globalisation are changing (Western) societies and how institutions such as the school, the hospital or the factory have become corporations. The difference lies in the process and the method. Where discipline aims to achieve a long-term, stable and docile society striving for the optimal use of resources to reach government-issued goals, corporations focus on short-term results. In order to do so, they need constant control, and this is achieved via continuous monitoring and assessment of markets, workforces, strategies, etc. The corporation is a fundamentally different being than the nation-state, because it does not strive for progress of society as a whole; it tries instead to control certain specific parts of - increasingly international-markets. To illustrate, the point is not to create a good and steady carpenter, but to know how and where to put a nail in a piece of wood as efficiently as possible. The carpenter has become a coded figure of corporation (Deleuze 1992), which means that his skills could be valuable 1 day, but, as markets change, useless the next. This is dubbed modulation (Deleuze 1992, 2), where systems or institutions are constantly changing and thereby also changing the fibres of society. A difference with Foucault's Panopticon is that these modulations take place in ways that are often invisible for the subjects or citizens. Where discipline for Foucault was effective because of its visibility and its active (yet involuntary) participation - you have to work/pass the exam/abide by rule X-Deleuze states that modulations happen in invisible or opaque networks that are unperceivable to individual citizens. As a result, surveillance also moves away from being a present and often physical force on individuals, to become more abstract and numerical:

The disciplinary societies have two poles: the signature that designates the individual, and the number or administrative numeration that indicates his or her position within a mass. This is because the disciplines never saw any incompatibility between these two, and because at the same time power individualizes and masses 
together, that is, constitutes those over whom it exercises power into a body and molds the individuality of each member of that body. [...] In the societies of control, on the other hand, what is important is no longer either a signature or a number, but a code: the code is a password, while on the other hand disciplinary societies are regulated by precepts.(Deleuze 1992, 179-180)

From watchwords in disciplinary societies to passwords in control societies, the point made by Deleuze in relation to surveillance is that individuals becomes less relevant as subjects of surveillance; it is no longer actual persons and their bodies that matter or that need to be subjected and disciplined, but rather the individuals' representations. It is the divided individual - consumers and their purchasing behaviourwho has become important to monitor and control. Deleuze coins this the dividual. Where society is becoming fragmented, so does the individual; the Panopticon blurs and the individual is split up into pieces, with the power of consumerism demanding all kinds of attention from citizen-consumers. In a Deleuzian society, the point is no longer making bodies docile, but to mould consumers, whose data-bodies become more important than their real bodies. Where Foucault would talk about the shift in power, from 'taking life or let live' towards an administration of life (bio-power) 'to foster or disallow life', Deleuze states that power has taken another shift towards controlling access. Consequently, Deleuzian places of interest are airports and borders, as access points (something taken up in later conceptualisations, see Section 4.1).

The notion of the dividual and the turn to access points as an object of study mark, a post-Foucauldian direction, and to some extent the beginning of 'surveillance studies' as a discipline beyond the mere understanding of panopticism. The Deleuzian notion of the dividual directs the gaze not towards individuals as complete or uniform beings, but rather towards individuals as entities with many roles, represented in many different places (data-banks). Where Foucault studied closed spaces and enclosed institutions, such as the factory, the prison or the hospital, striving to make individual bodies docile, Deleuze focuses on open spaces and points attention to control at a distance, using technologies of power that reform bodies (and minds) through daily regimes instigated by those in power. Where Deleuze can be seen as the founding father of post-Panoptical literature, he did so in a time when computers and the Internet were not yet as prevalent as they would become in the late 1990s and 2000s. The insight of looking at networks of power and the decoupling of individuals' bodies and their representations became a main inspiration and source for other surveillance scholars to build on, when computer technologies became more ubiquitous.

\subsection{Haggerty and Ericson's Surveillant Assemblage: Taking Down the Panopticon}

Two of the earliest and harshest critics of Foucault's Panopticon metaphor to analyse contemporary surveillance are Kevin Haggerty and Richard Ericson. In their influential paper 'The surveillant assemblage' (Haggerty and Ericson 2000), they state that the panoptic metaphor should not be over-stretched beyond recognition when trying to capture the new and different forms of surveillance today; rather, a new set of analytical tools is required. For several reasons, contemporary surveillance fundamentally differs from past surveillance for which the Panopticon was an appropriate metaphor, from Bentham's eighteenth-century Panopticons to modern-networked societies around 
1960. First, the panoptic model fit the idea of disciplinary societies, in which the primary purpose of surveillance is 'productive soul training': repression and productive development of modern selves, instilling the requirements of industrial capitalism in individuals themselves (Haggerty 2006). Second, in this model, a disproportionate level of surveillance was oriented towards the underclass, the poor and marginalised, leaving the mainstream unmonitored. Third, surveillance was limited to contained, physical spaces of total institutions, such as prisons, hospitals, schools and factories, and was generally seen as discretely bounded, structured and stable. And fourth, surveillance was done primarily by humans (although specific architectures were used in order to 'enhance' human monitoring capabilities). In order to provide a new set of analytical tools to capture contemporary surveillance, Haggerty and Ericson proposed the concept of 'surveillant assemblage', for which they drew inspiration from Deleuze and Guattari's concept of 'assemblages' and the idea of control societies. The shift in focus from territorial to de-territorialised forms of social control can be described as postPanoptic (Bogard 2006).

Deleuze and Guattari defined assemblages as a 'multiplicity of heterogenous objects, whose unity comes solely from the fact that these items function together, that they work together as a functional entity' (Haggerty and Ericson 2000). Beyond this functional entity, with a stability only on the surface, assemblages comprise of discrete flows of an essentially limitless range of phenomena, such as people, signs, chemicals, knowledge and institutions. These fluid and mobile flows become fixed into more or less stable and asymmetrical arrangements - assemblages, visualised as devices hosting opaque flows of auditory, olfactory, visual and informational stimuli. These assemblages turn into systems of domination allowing someone or something to direct or govern actions of others; the inevitability of transformation is key to thinking in terms of assemblage (Murakami Wood 2013). Surveillant assemblages can hence be seen as 'recording machines', since their task is to capture flows and convert them into reproducible events. Haggerty and Ericson used this concept, because they identified contemporary surveillance to be emergent, unstable and lacking discernible boundaries or accountable governmental departments, so that it cannot be criticised by focusing on single, confined bureaucracies or institutions. Thus, for example, they can include bottom-up surveillance reminiscent of Bentham's constitutional-Panopticon, with the many watching the few, although they admit that surveillance of the powerful is 'often a mile wile but only an inch deep' (Haggerty and Ericson 2000, 609). Thus, this new, post-panoptic surveillance:

(1) is driven by the desire to bring systems together, leading to an increased convergence of formerly discrete surveillance systems and an exponential increase in surveillance capacity;

(2) is increasingly growing and spreading by expanding its uses for purposes of control, governance, security, profit and entertainment, and with the help of new and intensified technological capabilities, particularly the rise of computerised databases;

(3) has a levelling effect on hierarchies of surveillance, due to new target populations being monitored with new and intensified technological possibilities;

(4) works across state as well as non-state institutions;

(5) is primarily directed towards human bodies that are understood as a hybrid composition - a flesh-technology-information amalgam; and 
(6) relies on machines to make and record discrete observations (Haggerty and Ericson 2000).

Due to its ever-increasing growth and expanding uses of surveillance, its levelling effect on hierarchies of surveillance and its regenerative qualities, surveillance has been described as rhizomatic, another concept taken from Deleuze and Guattari. (Rhizomes are plants that grow in surface extensions through interconnected vertical root systems - this way of growing is contrasted with arborescent plants, which have a deep root structure and grow along branchings from the trunk.). These new characteristics of surveillance fit well with the idea of a control society replacing the disciplinary society, in which citizens are no longer subject to disciplinary or simple repressive modes of surveillance in confined spaces (with power as an element of the interior of separated spaces, see Romein and Schuilenburg 2008); rather, citizens are being increasingly constituted as (merely or primarily) consumers 'seduced into the market economy'. Hence, surveillance today is used increasingly to construct and monitor consumption patterns (rather than perform 'soul training'), constructing consumer profiles in order to limit access to places and information, leading to the offering or refusal of social perks, such as credit ratings or rapid movement through customs. Because of this leading purpose of contemporary surveillance, monitoring is often directed towards the human body for the purpose of canalising access to places and information and allowing for the production of consumer profiles through the ex post facto reconstruction of people's behaviour, habits and actions. Such surveillance takes place in two consecutive steps: de-territorialisation and re-assembly. The body is first broken down, abstracted from its physical setting, only to then be re-assembled in different settings through a series of data flows. The result is a decorporealised body, more mobile and measurable than its physical counterpart, re-assembled in the by now wellknown 'data double' (Haggerty and Ericson 2000, 611). The data double, however, goes beyond representation of our physical selves - it does not matter whether the double actually corresponds to the 'real' body. The data double constitutes an additional self, a 'functional hybrid' (Hier 2002, 400), serving foremost the purpose of being useful to institutions, which allow or deny access to a multitude of domains (places, information, things) and discriminate between people. The doubles flow through a host of scattered 'centres of calculation' (e.g. forensic laboratories, statistical institutions, police stations, financial institutions and corporate and military headquarters) in which they are re-assembled and scrutinised for developing strategies of administration, commerce and control; however, the whole system is based on the (capitalist) idea of 'surplus value' or, in this case, 'surplus information'. The chief idea is that from all the data that people generate in daily behaviour (using credit cards, browsing the Internet, using smartphone applications, working, travelling, walking on the street, etc.), profit should be made.

In the 2006, the paper 'Tear down the walls: on demolishing the Panopticon', Haggerty offers additional or different characteristics of contemporary surveillance than discussed in the 2000 paper with Ericson; this might be seen as a (partial) critique of the concept of the surveillant assemblage. First, he emphasises the proliferation of new purposes of surveillance, giving numerous examples: deterrence, consumption, entertainment, titillation, health promotion, education, governance, accountability, 
child-rearing and military conquest (Haggerty 2006). Because these uses are not necessarily established in advance but are emergent, resulting from the creative insights of individuals who envision novel possibilities for systems developed for entirely different purposes, it is increasingly difficult to suggest that surveillance serves a single coherent purpose such as social control, or even a limited set of purposes. Moreover, surveillance can also be enjoyable, since both watching and exposing oneself can be pleasant entertainment activities at times, even playing a role in identity formation. On the other hand, although there is undeniably a greater visual and documentary scrutiny of the powerful today than at any point in the past, Haggerty admits that surveillance continues to play an important role in establishing and reinforcing social inequalities (Haggerty 2006). Haggerty also emphasises that the focus on people as targets of surveillance (covering both human bodies and non-physical representations) neglects an enormous volume of surveillance, in which humans are implicated only in a tangential fashion, such as satellite imaging, in which the planet and nature are being monitored. And last, Haggerty highlights the fact that awareness of surveillance is no longer required for most prominent surveillance projects to achieve their goals; many even require secrecy, e.g. dataveillance (surveilling people's behaviour through the increasingly intensive data trails that their behaviour generates, see Clarke 1988). With these additional thoughts on contemporary surveillance, a somewhat amended concept of the surveillant assemblage, as seen by Haggerty, emerges, one that deals with surveillance and its effects in a more neutral (less negative) way.

This overview of surveillant assemblages and the characteristics of contemporary surveillance demonstrates a quantitative turn towards people and other surveilled phenomena. It is no longer (physical) individuals who needs to become visible and controlled, rather, the focus is on their data doubles (who need not be a double at all), the data that individuals leave behind and are then re-assembled according to the purpose it is supposed to serve. Data about us, this 'pure virtuality', is almost uncontrollably flowing in cyberspace (a conceptual space within ICTs, combining technologies of the Internet, virtual reality and conventional telecommunications, along with emerging hybrid spaces, see Dodge and Kitchin 2011) through different databases, inviting the linking of these different sources flows of data, or what Lyon calls 'leaky containers' (2001). If surveillance is something not given but changeable, a 'mode of ordering' responding to problems of government (Law 1992) but also something broader, a network of power and knowledge relations (in accordance with Foucault's thinking), surveillance should no longer be seen as relatively stable and physically contained, but as a malleable, fluid and unstable phenomenon, ever-flowing through cyberspace, perceptible to people as multiple surveillant assemblages (control networks, control circuits or 'Little sisters' (Romein and Schuilenburg 2008, 347). In other words, surveillance has become de-territorialised, operating as a heterogeneous network of elements and spreading rhizomatically (Murakami Wood 2013). Social control today is, thus, decentralised and shape-shifting - it is not focused just on collecting information but on decoding and recoding, sorting, altering, circulating and re-playing information (Bogard 2006). However, as Haggerty pointed out, surveillance studies tend to neglect surveillance practices that might be accepted as a positive development (e.g. in science and medicine). The expanded 'networked control' should not be perceived as a purely negative concept, but as one that also offers possibilities for entertainment, pleasure and counter-power, and moreover, one that also facilitates de-territorialised forms of resistance as a function of its own organisation. 


\subsection{Surveillance Capitalism}

A third and relatively recent strand in theorising surveillance from a post-panoptic perspective is (neo-)Marxist surveillance theory. Connecting the thought of Marx to surveillance is not entirely new (see Fuchs 2012a for an overview). In fact, Marx himself saw surveillance as a fundamental aspect of the capitalist economy and the modern nation state, understanding surveillance as both an economic and a political concept (Fuchs 2012b). Surveillance is thus a coercive and technological method for controlling and disciplining workers, but it is also a political process of domination, which includes a potential for counter-surveillance through the press. Some scholars have started to apply the stages of Marx's cycle of capital accumulation to the concept and practices of surveillance: applicant surveillance in the stage of capital circulation; workplace, workforce and property surveillance in the stage of capital production; and consumer surveillance and surveillance of competitors in the cycle of circulation (Allmer 2012; Fuchs 2012a). Other scholars, such as Mathiesen, Andrejevic and Ogura, are implicitly or explicitly deploying Marxist concepts such as exploitation, class, fetishism, ideology critique or culture industry in their analysis of surveillance.

Within the strand of (neo-)Marxist approaches to surveillance, the contours of a theoretical framework are emerging that is somewhat similar to Haggerty and Ericson's surveillant assemblage, but which goes further in conceptualising surveillance as a dominant and overarching feature of capitalist society. This framework can be called 'surveillance capitalism', a term possibly first used by Bellamy and McChesney (2014), but more thoroughly developed and disseminated by Zuboff $(2015,2016)$. Although surveillance capitalism is not yet fully developed as a theory, Zuboff (2015) is laying a foundation for a new 'all-encompassing theory' at a 'civilizational scale', attempting to explain a new type of social relations and economic-political system that produce their own conceptions and uses of authority and power. Such an overarching theory is needed, because '[t]oday's surveillance complex aligned with an economic base enthralled with the prospects of metadata appears too strong for meaningful reforms without significant shifts in larger economic foundations' (Price 2014).

Surveillance capitalism is a new subspecies of (information) capitalism that has gradually constituted itself during the last decade, in which 'profits derive from the unilateral surveillance and modification of human behavior' (Zuboff 2016). This new type of capitalism is said to have been hijacked by surveillance, which now has a wholly new logic of accumulation fitting a networked world - aiming to predict and modify human behaviour as a means to produce revenue and market control (Zuboff 2015). Zuboff's surveillance capitalism thus signals a new era of capitalism with a new dominant logic of accumulation, claiming that the contemporary, very lucrative surveillance project subverts and corrupts the normal evolutionary mechanisms of capitalism - the unity of supply and demand that, however imperfectly, catered to the genuine needs of populations and societies and enabled the fruitful expansion of market democracy (Zuboff 2016). In contrast,

\footnotetext{
${ }^{9}$ Stated by David Lyon at CPDP in January 2016, 2016: Surveillance capitalism: a new societal condition rising (video available at https://www.youtube.com/watch? $=0$ Fr7zl9NA7s, accessed 02 April 2016); also see Zuboff's 2016 forthcoming book, Master or Slave: The Fight for the Soul of Our Information Civilization, to be published by Eichborn in Germany and Public Affairs in the U.S.
} 
surveillance-based capitalism no longer has any connection or interest in the needs of populations, societies or states.

What is called big data is the foundational component of this new economic logic, which is based on prediction and its monetization - selling access to the real-time flow of people's daily life in order to directly influence and modify their behaviour for profit. The pervasive and ubiquitous recording of all daily transactions also means that the market is no longer unknowable as it still is in classical liberalism; rather, it is becoming transparent and knowable in new ways (Zuboff 2015; Varian 2014). It comes as no surprise that Google is seen as the ideal type of the new economic logic and commercial model.

Zuboff identifies four key features of the emerging logic of capital accumulation, in which she explicitly follows the four new 'uses' emanating from computer-mediated transactions identified by Google's Chief Economist, Hal Varian (Varian 2014). First, the insatiable appetite for data extraction and analysis (data mining), commonly known as big data, illustrates the two possibly most crucial features of surveillance capitalism: formal indifference and functional (or structural) independence. Formal indifference represents the asymmetric nature of data extraction, which occurs in the absence of dialogue or (freely given and informed) consent. Functional independence breaks with the twentieth-century corporation model, since there are no structural reciprocities between the firm and its primary populations (durable careers for employees, longterm relationships with customers, Zuboff 2015). Instead, firms like Google rely on algorithms to manage their core services and on relationships with third parties (advertisers and intermediaries) for their revenue. The infrastructure of surveillance capitalism, built on big data with its goal of prediction and behaviour modification, eliminates the need for-or possibility of - feedback loops between the firm and its users.

Second, surveillance capitalism involves real-time monitoring of contractual performance along with real-time, technology-enabled enforcement of the contract (Zuboff 2015). In a world where such a system of contractual monitoring and enforcement is the norm, 'habitats inside and outside the human body are saturated with data and produce radically distributed opportunities for observation, interpretation, communication, influence, prediction and ultimately modification of the totality of action', establishing a new architecture from which there is no escape, making the Panopticon seem prosaic. Where power was previously identified with ownership of means of production, it is now constituted by ownership of means of behavioural modification (Zuboff 2015, 82). Third, services are personalised and customised, telling you what you want or need to know ('even before you know it yourself'). This feature produces substantial new asymmetries of knowledge and power (Zuboff 2015, 83). Fourth, the technological infrastructure allows for and requires continual experimentation and intervention into users' lives. Since big data analysis yields only correlations, continual experimentation should attempt to tease out causality. A textbook example is Facebook's experiment to secretly influence its users' mood. Thus, 'behaviour is subjugated to commodification and monetisation' (Zuboff 2015, 85), which is the dominating logic of twenty-firstcentury market dynamics.

Zuboff would be first to admit that these contours of surveillance capitalism require further theorisation and development. Nevertheless, what she tries to show is that surveillance as a key part of the new logic of accumulation goes well-beyond privacy considerations. She tries to show that it threatens democracy itself, because it does away with the political canon of the modern liberal order, which was defined by the 
foundational principles of self-determination - in individuals' private life and social relations, politics and governance.

\section{Phase 3: Contemporary Conceptualisations- the Branching Out of Surveillance Theory}

The previous section featured authors attempting to get away from the Panopticon model. The idea of internalisation of control via one-directional top-down architectures of surveillance no longer seemed to fit contemporary societies mainly because Foucault did not, and could not, include electronic layers of surveillance, which was the main focus of authors in phase 2 . In this light, surveillance seems a technology-dependent concept; ideas about surveillance shift along with new technologies that challenge existing forms of societal organisation and governance. But does that imply there are no anchor points that go beyond theories running after each technological trend? Describing surveillance in relation only to the latest technological trend to then analyse how this differs from the former situation, might not be enough to make us understand and potentially change the way we deal with different forms of surveillance in society. ${ }^{10}$ The problem of surveillance theory here is that the increase in size and complexity of surveillance practices seems to make it almost impossible to develop an over-arching theory of surveillance that captures surveillance as a largely unitary concept or phenomenon, as in Foucault's or Deleuze's theories. Rather, surveillance theory in what we can call phase 3, which builds on but also moves beyond the Panopticon and digital surveillant networks and assemblages, branches out in different directions. Thus, the third phase is characterised not so much by comprehensive theories, but rather by particular surveillance concepts or diagrams (Elmer 2003) studied in specific contexts or case studies. In phase 3, surveillance scholars re-visit and build on concepts and theories from phases 1 and 2 . The shift in analysis from disciplinary to control societies, for instance, is relatively young, and it would be cutting corners to dismiss Foucault's analysis of centuries of development in European history merely because our sociotechnical lifeworld has changed in recent decades. On the other hand, surveillance does remain closely linked to technologies, and the on-going development of technological tools implies that concepts of surveillance do need to be regularly re-visited and rethought, to offer relevant perspectives on how our world takes shape. In this section, we give examples of the different ways in which surveillance theories and concepts of phases 1 and 2 are being used and re-visited. Whilst a comprehensive overview is impossible to give here, we think the examples chosen are illustrative of the different directions in which surveillance theory is branching out from the previous phases.

\subsection{New Forms of Panopticons}

After $9 / 11$, the surveillance industry has vastly increased in both form and content. The Snowden revelations have shown that nation-states conduct mass surveillance of communications, of both foreign and domestic citizens. They have done so all too

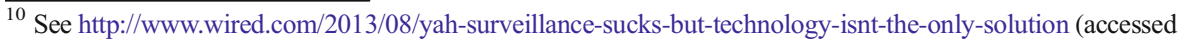
04 April 2016). 
often in conjunction with commercial parties and service providers. Furthermore, the emergence of social media has made the roles of watcher and watched and power relations in society more diffuse - we are letting ourselves be watched collectively and (seemingly) voluntarily, and we eagerly watch each other and the watchers. The Panopticon as a metaphor could still be productive to explain how surveillance works and what it does, albeit in adjusted forms. As David Lyon, a leading author in the field, states: 'we cannot evade some interaction with the Panopticon, either historically, or in today's analyses of surveillance' (Lyon 2006, 4). This, he claims, is due to the evergrowing presence of 'watching and being watched' through all kinds of new technologies.

Where the Panopticon idea and the goal of creating docile subjects have spread from the prison to, for instance, the workplace and governments for reasons of productivity and efficiency, they have also travelled to 'softer' forms, such as entertainment and marketing. Through reality shows and YouTube, to be watched is even becoming an asset and a social norm (the YouTube-logic is: the more views the better). Lyon (2007) calls this 'panopticommodity' and Whitaker (1999) frames it 'participatory Panopticon', by which they conceptually try to project ideas of watching and being watched as a form of discipline onto current, contemporary manifestations of what is basically Foucault's panoptic principle.

Bruno Latour also delved into surveillance concepts by coining the Oligopticon; 'governance has thus consisted of a set of partial vantage points from fixed positions with limited view sheds' (Latour as cited in Dodge and Kitchin 2011, 85). Each of these sheds has its own particular gaze and its own methods and related technologies'things' - through which it operates. The partial vantage points of the Oligopticon, however, are increasingly linked as databases are connected. Moreover, the number of vantage points has increased post-9/11 (think of Deleuzian points of surveillanceaccess or checkpoints that citizens encounter in daily life). Bigo (2006), in an attempt to conceptualise $9 / 11$ and what it did to notions of control, freedom and security, has coined the term BANopticon. Instead of monitoring and tracking individuals or groups to capture misbehaviour, the BANopticon aims at keeping all the bad ones out; it bans all those who do not conform to the rules of entry or access in a particular society. He points out that a series of events, most prominently the 9/11 attacks, have triggered a (constant) 'state of unease' and an American-imposed idea of global 'in-security' (Bigo $2006,49)$. This leads to a rhetoric of 'better safe than sorry' under which an increase of surveillance measures could take place. This rhetoric also paved the way for experimentation with new surveillance technologies, such as body scanners at airports, and the accelerated introduction of biometric passports and experiments with motion tracking at Schiphol Airport (van der Ploeg 2003), for instance. Most of these measures are situated in Deleuzian access points, such as airports and border controls. Some scholars point out that societies emerging after $9 / 11$ can be termed true surveillance societies, in which every citizen is a potential threat needing to be monitored (i.e. Lyon 2001). In that sense, the Panopticon as a diagram re-emerges; the access points create again a confined and bordered space where both visitors and inmates suffer a constant gaze. Lyon (2006) states that we do not have to dismiss the idea of the Panopticon, but that other sources of theory can also be found. This can help in creating more balanced and more informed analyses of current surveillance practices and/or to re-frame phenomena into refined theories or concepts of surveillance. 


\subsection{Building on Deleuze: Dataveillance and Social Sorting}

Another contemporary branch in surveillance studies, featuring in both surveillance studies and media studies, elaborates the notion of 'dataveillance'. As mentioned earlier, Clarke (1988) coined the term dataveillance to indicate that through computational means and digital information, it has become easier for governing actors to trace individuals or groups than was possible with the previous, often expensive and 'heavy' forms of architectural or institutional surveillance. Although databases existed before the computer, they involved equally 'heavy', analogue methods of gathering and storing information. Moreover, present forms of surveillance potentially have more impact and shaping power on citizens' daily life than pre-Internet paper-based data entries because of the accessibility of digital databases and the relative ease of combining and sharing different types of data (Marx 2002). This has many implications for surveillance, because both in type and in amount information in these databases about different aspects of citizens' lives has vastly grown in recent decades. Recalling Deleuze's notion of the dividual, these different aspects represent parts of an individual, interesting for different actors for different reasons. A temporal difference with Deleuze's analysis in the 1980s is that it is becoming increasingly unclear for individuals where their data resides, what kinds of correlations and profiles are being made and who is using this data for which purposes. Besides, many current data entries are not obligatory or forced — often people provide them happily and voluntarily - which makes it difficult to analyse dataveillance in terms of a digital Panopticon or as disciplining power. Data use has become opaque and the clear connection between guard and inmate, watcher and watched, is lost. The role of the Internet and new media in society has been acknowledged and researched by (amongst others) media and surveillance scholars, who argue that the ways in which we lead our life has rigorously changed. However, despite the prevalence of dataveillance and masssurveillance of communication by governments and companies alike, the question whether and to what extent dataveillance actually alters society and public life in terms of discipline or control has yet to be answered. Productive surveillance concepts to be applied in this context are social sorting and adjacent concepts such as profiling, data doubles and predictive policing (to name a few).

Social sorting stems from a fear of others (Bigo 2006; Lyon 2003). To exemplify, several studies have been performed to explore social sorting empirically in the context of CCTV (Lyon 2003; Dubbeld 2005), showing that, despite increased reliance on software and protocol, social sorting still occurs often as a result of a white, male gaze in the CCTV control room, having a particular bias that leads to certain profiles of deviance. With the coming of more forms of automated surveillance, social-sorting processes might be more hidden or transposed into algorithms. The proponents of computerised and automated forms of surveillance foresee more objectivity: they argue that social sorting and arbitrary judgement, being a result of human (mis)judgments and prejudice, could be replaced by 'objective' software. In contrast, Galloway (2004) and others, in line with critical, Marxist ${ }^{11}$ perspectives, do not believe that technological

\footnotetext{
${ }^{11}$ See for example, Fuchs and Mosco, Introduction: Marx is Back - The Importance of Marxist Theory and Research for Critical Communication Studies Today (2012); Fuchs, New Marxian Times! Reflections on the 4th ICTs and Society Conference "Critique, Democracy and Philosophy in 21st Century Information Society. Towards Critical Theories of Social Media” (2012a).
} 
sorting will be 'fairer' than human-based sorting in surveillance practices. This may be due to the fact that the so-called enforcer-class (police officers, CCTV operators, bouncers and other surveillance workers) consists mainly of a specific demographic, but also because of how the monitoring software is designed and which action possibilities or affordances (Gibson 1977) and responsibilities are inscribed in the software and hardware that the enforcer-class uses (Timan and Oudshoorn 2012). The concept of surveillant assemblages (see Section 3.2) could be used to study in concrete practices to what extent discipline and control are being transferred to automated, computerised processes and how this changes the normative structure of surveillance (Andrejevic 2007). Current surveillance practices show that, along with the rise of a surveillance class, this class serves political goals and powers that go beyond an objectivation of surveillance through smart and more efficient algorithms. Rather, against the grain of post-panoptical theories that warn against digital networks and automated surveillance as the upcoming loci of control, there are still physical and local surveillance realities that work next to, or in conjunction with, digitised and computerised networks. These surveillance realities still await proper conceptualisation.

\subsection{Participation and Empowerment in Surveillance}

Moving away from the often dystopian or at least dark types of surveillance analysis that are particularly present in post-structuralist and post-Marxist scholars from Deleuze to Galloway, another branch has emerged in contemporary surveillance studies. Introduced by Haggerty, more neutral and sometimes even empowering accounts are discerned in systems of watching and being watched. If we accept that we live in a networked and technology-saturated society, it follows that apparatuses of surveillance, the methods, tools and technologies already mentioned by Foucault are not solely in the hands of power-hungry institutions, companies or governments. Even if we follow Deleuze in reasoning that corporations are now the main surveilling actor, with a surge for power and control that is enhanced by their opaqueness, still individuals can, at least to some extent, resist and refuse, mainly by finding alternative ways of using technology that is increasingly accessible to him or her. The extent to which this is possible, however, is subject of current debates surrounding mass surveillance. Instead of being a place where one looks at many, most social media technologies follow the logic of 'many look at many', where visibility is often deliberately chosen. In that vein, Albrechtslund (2008) in particular diverts from solely negative concepts of surveillance. Rather, he argues that since the emergence of ubiquitous computing, surveillance as a concept should be re-considered; 'The entertaining side of surveillance is a phenomenon worth studying in itself, and we expect that this type of study will contribute to an understanding of the multi-faceted nature of surveillance' (Albrechtslund and Dubbeld 2005, 3).

Albrechtslund looks at how surveillance is often used as a design principle in, for instance, online games and sports-tracking services. Besides a fun aspect, such games and services can also inform us about how a (part of) society reflects on notions of surveillance. Albrechtslund coins the term 'participatory surveillance'; citizens/users are actively engaged in surveillance themselves as watchers, but they also participate voluntarily and consciously in the role of watched. Many online environments, especially social networking sites (boyd and Ellison 2007), serve as interesting places of 
study, since many beliefs, ideas and opinions are shared there. Boyd and Ellison (2007) even state that social networking sites are dominating online activities today and as such, they constitute new arenas for surveillance. From the perspective of users and visitors of these online places, the high level of surveillance, in the form of tracking and being tracked, watching and being watched, or sharing and being shared, is not necessarily negative:

Characteristic of online social networking is the sharing of activities, preferences, beliefs, etc. to socialize. I argue that this practice of self-surveillance cannot be adequately described within the framework of a hierarchical understanding of surveillance. Rather, online social networking seems to introduce a participatory approach to surveillance, which can empower - and not necessarily violate - the user. (Albrechtslund 2008)

Participating via, for instance, sharing, responding or 'liking' engages users into these platforms, where the idea of being seen and 'followed' is a precondition rather than a setback. This is also called self-surveillance, a term that, with recent technological trends such as mobile healthcare applications (mHealth) and wearable computing, resonates more and more. The added value of this concept is that it allows for a usercentred perspective on surveillance, rather than a top-down or institutional analysis. Following boyd (2011) and Marwick (2012), this approach enables another type of analysis of surveillance, where tracing behaviour can reveal users' experiences of surveillance and visibility. On the question why visibility is so important to these users, Koskela (2011) for instance explains that exhibitionism such as shown on social networking sites or in TV shows can work in an empowering way. By throwing everything into public arenas, 'visibility becomes a tool of power that can be used to rebel against the shame associated with not being private about certain things. Thus, exhibitionism is liberating, because it represents a refusal to be humble' (Koskela 2004). Similarly, in the marketing context, Dholakia and Zwick argue that ultraexhibitionism 'is not a negation of privacy but an attempt to reclaim some control over the externalisation of information. As such, ultra-exhibitionism is to be understood as an act of resistance against the surreptitious modes of profiling, categorization and identity definition that are being performed by others on the consumer whenever he or she enters the electronic "consumptionscape" (Dholakia and Zwick 2001, 13).

A counter-argument to the empowering view of (self-)surveillance, however, is that emerging forms of self-tracking in for example mHealth or other measurement apps in combination with participation as a design principle could be seen as a facade or illusion of self-control, where actually users are being tracked and traced in the background. From a neoliberal point of view, one can also interpret self-tracking and self-surveillance apps as the ultimate model of 'nudging' (Sunstein and Thaler 2009), in which governments, institutions and companies are pushing back responsibilities (for health, for instance) onto individuals (Cohen 2016). In a way, this view re-introduces the Panopticon as a fitting metaphor-we are not only internalising doing good via external influences of (partly digitised) institutions in surveillant assemblages, but we are also, through self-monitoring apps and other forms of participatory surveillance, internalising these rational models and methods in a self-induced process of selfdisciplining. 


\subsection{Sousveillance and Other Forms of Resistance}

Another conceptual axis along which surveillance in phase 3 is analysed, concerns the level and type of resistance that is possible and present in certain contexts. One concept that emerged in the early 2000s is Steve Mann's 'sousveillance' (Mann 2004), a mode of monitoring in which citizens watch governing bodies from below, as an opposing concept to surveillance - watching over or from above. Due to an increased availability of camera equipment and other recording devices, Mann argues one form of resistance is (and should be) to 'watch back' at those who watch us. Where Mann uses the example of wearable cameras to watch back at CCTV cameras, the idea of sousveillance could also be transposed to the digital or the virtual context, where citizen journalism and publishing (leaked) information about surveillance actors can be seen as forms of watching back. Also, in analysing processes of social sorting and exclusion, it can prove insightful to look into forms of resistance and sousveillance to investigate whether and how individuals and groups resist current forms of surveillance, dataveillance and surveillance capitalism. As end-users of social media, as feeders of 'big data' or as 'implicated actors' (Clarke and Montini 1993) of CCTV or WiFi tracking, people still have some room for negotiation and resistance-for 'antiprograms' (Latour 1999) in use. Examples are citizens who choose to avoid CCTV cameras in cities (Brands and Schwanen 2014), wear anti-drone hoodies, ${ }^{12}$ instal free software (like 'Detekt') ${ }^{13}$ that detects spyware on your computer or feed faulty data into algorithms. $^{14}$

Although surveillance studies sometimes offers such practical cases and techniques to dodge surveillance (for example Roessler 2002), conceptualisations of resistance or 'pushing back' are as yet quite scarce. This might be connected to two asymmetry problems: first, an asymmetry of power, since we rarely get to choose whether or how we are monitored, what happens to information about us and what happens to us because of this information; and second, an asymmetry of knowledge, since we are often not (fully) aware of the monitoring and how it works at all (Brunton and Nissenbaum 2013). These two asymmetries can reinforce our lack of resistance, since how can we resist something that we do not understand, know about and often simply can hardly influence?

A notable exception is the concept of 'obfuscation', made particularly prominent by Brunton and Nissenbaum $(2013,2015)$. They provide tools and a rationale for evasion, noncompliance, refusal and even sabotage, particularly aimed at average users who are not not in a position to 'opt out' or exert control over their data, but also offering insights to software developers (to keep their user data safe) and policy makers (to gather data without misusing it). They invoke the notion of 'informational self-defence' in order to define obfuscation, which they see as a method of informational resistance, disobedience, protest or covert sabotage to compensate for the absence of other protection mechanisms and which aids the weak against the strong (Brunton and Nissenbaum 2013). Obfuscation in its broadest form thus 'offers a strategy for mitigating the impact of the cycle of monitoring, aggregation, analysis and profiling,

\footnotetext{
${ }^{12}$ See https://ahprojects.com/projects/stealth-wear (accessed 04 April 2016), for instance.

${ }^{13}$ See https://resistsurveillance.org/ (accessed 04 April 2016).

${ }^{14}$ See https://cs.nyu.edu/trackmenot/ (accessed 04 April 2016), for instance.
} 
adding noise to an existing collection of data in order to make the collection more ambiguous, confusing, harder to use and, therefore, less valuable' (Brunton and Nissenbaum 2013, 169). They offer wide-ranging examples, from 'quote stuffing' in high frequency trading to the swapping of supermarket loyalty cards. Many obfuscation tools, such as Tor/and proxy servers, are however still not widely known or deployed outside the relatively small circles of the privacy-aware and the technologically savvy; moreover, they come with transaction costs (e.g. Tor can be slow and is blocked by many large websites, Brunton and Nissenbaum 2013, 168). They also discuss certain ethical and political scruples (Mercer 2010; Pham et al. 2010; Brunton and Nissenbaum 2013) to indicate that obfuscation is not a panacea to address the downsides of surveillance. Nevertheless, Brunton and Nissenbaum see obfuscation as both a personal and a political tactic and therewith offer a theoretical account of resistance that can serve as a platform for further studying legitimate and problematic aspects of surveillance and its opposition in an age of ubiquitous data capture.

\section{Conclusion}

In this paper, we have given an overview of key theoretical frameworks and conceptualisations in surveillance theory. This mapping of the field may assist surveillance studies as it is increasingly feeding into and fed by a wide range of disciplines, each of which brings their own perspective, concepts and assumptions to understanding surveillance. We think it is important that surveillance scholars-not only those positioning themselves within surveillance studies but also those contributing to other disciplines - have a common ground for discussion and further development of the field. We hope that the overview in this paper can serve as such. It is particularly relevant for newcomers to the field that there is much more to understanding surveillance than Foucault's panopticism.

We have structured surveillance theory in three roughly chronological-thematic phases. The first two attempt to theorise surveillance by offering comprehensive theoretical frameworks, whilst the third further conceptualises surveillance, without developing alternative holistic frameworks but rather building on the insights of the first two.

The first phase, featuring Bentham and Foucault, revolves around the Panopticon and panopticism. It can be characterised as offering architectural theories of surveillance, where surveillance is largely physical and spatial in character (either in concrete, closed places such as institutional buildings or more widespread in territorially based social structures) and largely involves centralised mechanisms of watching over subjects. Panoptic structures are theorised as architectures of power; through panoptic technologies, surveillance enables power exercise, not only directly but also, and more importantly, through (self-)disciplining of the watched subjects.

The second phase moves away from panoptic metaphors and shifts the focus from institutions to networks, from relatively ostensible forms of discipline to relatively opaque forms of control. This phase can be characterised as offering infrastructural theories of surveillance, where surveillance is networked in character and relies primarily on digital rather than physical technologies. It involves distributed forms of watching over people, with increasing distance to the watched and often dealing with 
data doubles rather than physical persons. A common element in the different theoretical accounts of Deleuze, Haggerty and Ericson and Zuboff is to critically question not only the power structures in contemporary network societies and how surveillance reinforces, or sometimes undermines, these, but also how we can conceptualise this power play beyond panoptic effects of self-disciplining.

In the third phase, we see surveillance theory building on, and sometimes combining insights from, both theoretical frameworks of the first two phases, to conceptualise surveillance through concepts or lenses such as dataveillance, access control, social sorting, peer-to-peer surveillance and resistance. With the datafication of society, surveillance combines the monitoring of physical spaces with the monitoring of digital spaces. In these hybrid surveillance spaces, not only government or corporate surveillance is found, but also self-surveillance and complex forms of watching-and-beingwatched through social media and their paradigm of voluntary data sharing.

The roughly chronological structure should not be interpreted as consecutive stages. Each phase continues to the present (see Fig. 1). New comprehensive theories may emerge within the architectural or, more likely given the predominance of digital infrastructures in today's society, infrastructural strands of surveillance theory. Moreover, the conceptualisations of the third phase add to and refine the broad theoretical frameworks of the first two phases.

So, where does surveillance theory stand now? In the past two decades, many new layers have been added to real-space surveillant assemblages, with systems such as dataveillance supplementing rather than replacing classic systems of surveillance such as CCTV. In that sense, the Panopticon remains a powerful metaphor. However, the institutions that Foucault recognised as disciplining forces have altered in shape, place, visibility and dynamics. In addition, notions of self-surveillance point to new dynamics, where watching oneself via a mediated, mobile and networked gaze still raises questions of power, discipline and control, but in potentially new ways that cannot be easily captured in classic surveillance frameworks. Thus, many contemporary theoretical approaches to surveillance revolve around de-centralised forms of surveillance, with many watching many and with various permutations of machines and humans watching machines and humans. What binds many strands together are core questions of power and control, of who watches whom in which settings for what reasons; and these questions are asked in settings of technological infrastructures and tools, where technology functions as an intermediary of power or control dynamics.

These questions of power and control are approached differently, however. Gary T. Marx distinguishes three attitudes in surveillance thinking. One view emphasises historical continuity, arguing that changes in surveillance are a matter of degree; others argue that changes in surveillance are revolutionary, making surveillance a much more predominant feature of current society. The latter outlook has two variants: a completely negative view ('you never had it so bad') and a more relativistic view, arguing that whilst the technologies may be revolutionary, changes in surveillance largely reflect social and cultural changes (Marx 2002).

Related to this are differences in understanding the role that surveillance and surveillance technologies play in society: some theorists use surveillance as a lens to observe, understand or criticise certain phenomena or developments, whilst others approach surveillance as an intrinsic and fundamental feature of society as a whole. Whilst the former is usually more situated in concrete practices, the latter approach is more holistic and generic, attempting to explain broad developments in society as being related to the fundamental affordances of surveillance in structuring social processes. 


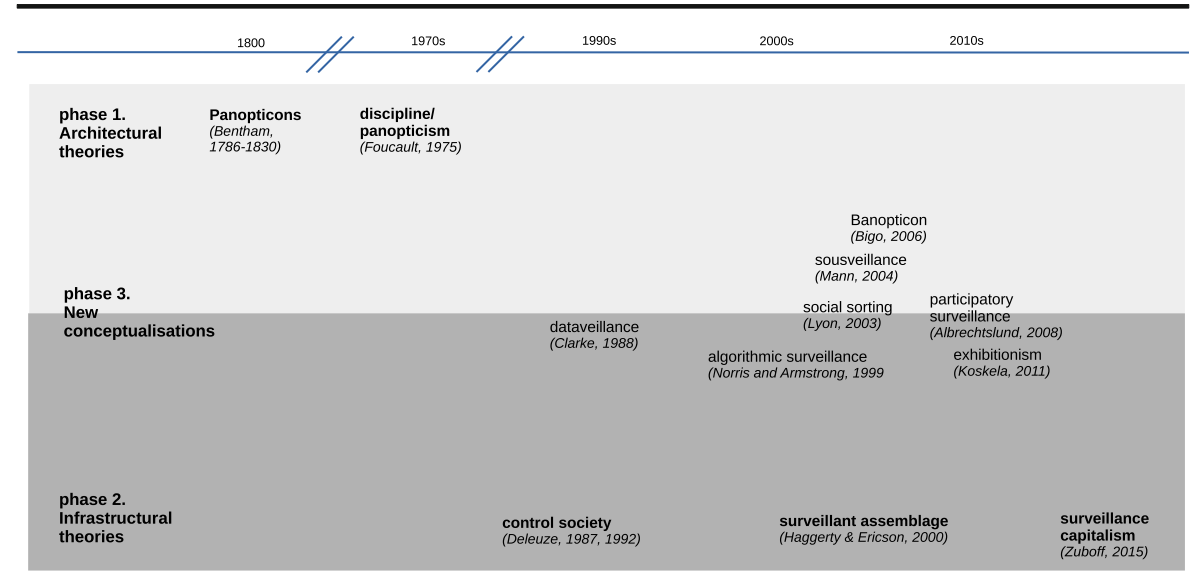

Fig. 1 Three phases of surveillance theory

One pitfall of seeing surveillance as an all-encompassing feature of society, but also in approaches where surveillance is used as a lens to analyse certain developments, is that theoretical accounts often talk in abstract entities ('institutions', 'the government', 'networks', 'the market'). These entities are described as invisible forces exercising power over subjects. This perspective often ignores any form of situatedness, context or the specificities of surveillance technologies and practices. In that respect, the surveillant assemblage can be seen as the first recognition that surveillance needs to be analysed in context. It is important to apply insights and methodologies developed by Science and Technology Studies, including for example Actor-Network Theory, to look beyond abstract theory and the frame of inevitable power exercise over passive, docile subjects. Although the technologies used in surveillance have been discussed in earlier surveillance literature, the mediation and remediation (Bolter and Grusin 1996) that occurs between technology and users are still frequently overlooked. Useful exceptions are scholars such as Dubbeld (2005); Ball and Webster (2003) and Taekke (2011), who provide useful examples of how Science and Technology Studies and media studies can help find new directions for thinking about the co-evolution of technologies, practices and values associated with surveillance in the twenty-first century.

Acknowledgments Research for this paper was made possible by a grant from the Netherlands Organisation for Scientific Research (NWO), project number 453-14-004. We thank the anonymous reviewers for their helpful suggestions.

Open Access This article is distributed under the terms of the Creative Commons Attribution 4.0 International License (http://creativecommons.org/licenses/by/4.0/), which permits unrestricted use, distribution, and reproduction in any medium, provided you give appropriate credit to the original author(s) and the source, provide a link to the Creative Commons license, and indicate if changes were made.

\section{References}

Albrechtslund, A. (2008). Online social networking as participatory surveillance. First Monday, 13(3), 3. Available at: http:/www.uic.edu/htbin/cgiwrap/bin/ojs/index.php/fm/article/view/2142/1949 (accessed 01 April 2016). 
Albrechtslund, A., \& Dubbeld, L. (2005). The plays and arts of surveillance: studying surveillance as entertainment. Policy Studies, 3, 216-221.

Allmer, T. (2012). Towards a critical theory of surveillance in informational capitalism. Frankfurt am Main: Peter Lang.

Andrejevic, M. (2007). iSpy: Surveillance and power in the interactive era. Lawrence: University Press of Kansas.

Ball, K., \& Webster, F. (2003). The intensification of surveillance: Crime, terrorism and warfare in the information era. Chicago: Pluto Press.

Bellamy Foster, J. \& McChesney, R.W. (2014). Surveillance Capitalism: Monopoly-Finance Capital, the Military-Industrial Complex, and the Digital Age. Monthly Review, 66(3). Available at: http:// monthlyreview.org/2014/07/01/surveillance-capitalism/(accessed 01 April 2016).

Bentham, J. (2010). The panopticon writings (Ed. M. Božovič). London: Verso Books.

Bigo, D. (2006). Security, exception, ban and surveillance. In D. Lyon (Ed.), Theorising surveillance: The panopticon and beyond (pp. 46-68). Portland: Willan Publishing.

Bogard, W. (2006). Surveillance assemblages and lines of flight. In D. Lyon (Ed.), Theorising surveillance: The panopticon and beyond (pp. 97-122). Portland: Willan Publishing.

Bolter, J. D., \& Grusin, R. (1996). Remediation. Configurations, 4(3), 311-358.

Boyd, D. (2011). Dear Voyeur, meet Flâneur... Sincerely, Social Media. Surveillance \& Society, 8(4), 505507.

Boyd, D., \& Ellison, N. B. (2007). Social network sites: definition, history, and scholarship. Journal of Computer-Mediated Communication, 13(1), 210-230.

Božovič, M. (2010). Introduction: 'An utterly dark spot. In M. Božovič (Ed.), The panopticon writings (pp. 128). London: Verso Books.

Brands, J., \& Schwanen, T. (2014). Experiencing and governing safety in the night-time economy: nurturing the state of being carefree. Emotion, Space and Society, 11, 67-78.

Brunon-Ernst, A. (2013a). Introduction. In A. Brunon-Ernst (Ed.), Beyond Foucault: New perspectives on Bentham's panopticon (pp. 1-16). Surrey: Ashgate Publishing.

Brunon-Ernst, A. (2013b). Deconstructing panopticism into the plural panopticons. In A. Brunon-Ernst (Ed.), Beyond Foucault: New perspectives on Bentham's panopticon (pp. 17-42). Surrey: Ashgate Publishing.

Brunon-Ernst, A., \& Tusseau, G. (2013). Epilogue: the panopticon as a contemporary icon? In A. BrunonErnst (Ed.), Beyond Foucault: New perspectives on Bentham's panopticon (pp. 185-200). Surrey: Ashgate Publishing.

Brunton, F., \& Nissenbaum, H. (2013). Political and ethical perspectives on data obfuscation. In M. Hildebrandt \& K. De Vries (Eds.), Privacy, due process and the computational turn (pp. 164-188). New York: Routledge.

Brunton, F., \& Nissenbaum, H. (2015). Obfuscation: a user's guide for privacy and protest. Massachusetts: MIT Press.

Clarke, R. (1988). Information technology and dataveillance. Communications of the ACM, 31(5), 498-512.

Clarke, A., \& Montini, T. (1993). The many faces of RU486: tales of situated knowledges and technological contestations. Science, Technology \& Human Values, 18(1), 42-78.

Cohen, J.E. (2016). The Surveillance-Innovation Complex: The Irony of the Participatory Turn. In D. Barney et al. (Eds.), The Participatory Condition. Minneapolis: University of Minnesota Press. Retrieved from http://papers.ssrn.com/sol3/papers.cfm?abstract_id=2466708 (accessed 01 April 2016).

CPDP (2016). Panel on Surveillance capitalism: a new societal condition rising (video available at https:// www.youtube.com/watch?v=0Fr7z19NA7s; accessed 02 April 2016).

Dalibert, L. (2013). Posthumanism and somatechnologies - exploring the intimate relations between humans and technologies $(\mathrm{PhD}$ thesis). University of Twente.

Deleuze, G. (1992). Postscript on the societies of control. October, 59, 3-7.

Deleuze, G. (1994). Désir et plaisir. Magazine littéraire 325, 59-65. English translation available at: http:// www.artdes.monash.edu.au/globe/delfou.html (accessed 02 April 2016).

Deleuze, G. (2006). Foucault. London: Continuum.

Deleuze, G., \& Foucault, M. (1972). Les Intellectuels et le Pouvoir. L'Arc, 49, 3-10.

Deleuze, G., \& Guattari, F. (1987). A thousand plateaus: capitalism and schizophrenia. Minneapolis: University of Minnesota Press.

Dholakia, N. \& Zwick, D. (2001). Privacy and consumer agency in the information age: between prying profilers and preening webcams. Journal of Research for Consumers, 1, available at http://www. jrconsumers.com/academic_articles/issue_1/DholakiaZwick.pdf (accessed 01 April 2016).

Dilts, A. \& Harcourt, B. (2008). Discipline, Security, and Beyond: A Brief Introduction. Carceral Notebooks, 4, 1-6. Available at: http://www.thecarceral.org/cn4_dilts-harcourt.pdf (accessed 01 April 2016). 
Dodge, M., \& Kitchin, R. (2011). Code/space: software and everyday life. Massachusetts: MIT Press.

Dubbeld, L. (2005). The role of technology in shaping CCTV surveillance practices. Information, Communication \& Society, 8(1), 84-100.

Elmer, G. (2003). A diagram of panoptic surveillance. New Media \& Society, 5(2), 231-247.

Foucault, M. (1980). Power/knowledge: selected interviews and other writings 1972-1977 (Ed. C. Gordon). New York: Pantheon Books.

Foucault, M. (1991a). Discipline and punish: the birth of the prison. London: Penguin.

Foucault, M. (1991b). The Foucault effect: studies in governmentality (Eds. G. Burchell, C. Gordon \& P. Miller). Chicago: University of Chicago Press.

Foucault, M. (1998). The will to knowledge: the history of sexuality (Vol. 1). London: Penguin.

Foucault, M. (2002). Power: essential works of Foucault 1954-1984, Vol. 3 (Ed. J.D. Faubion). London: Penguin Books.

Foucault, M. (2006). Psychiatric power: lectures at the collège de France 1973-1974 (Ed. J. Lagrange). New York: Palgrave Macmillan.

Foucault, M. (2007). Security, territory, population: lectures at the collège de France 1977-1978 (Ed. M. Senellart). New York: Picador.

Fuchs, C. (2012a). Political economy and surveillance theory. Critical Sociology, 39(5), 1-17.

Fuchs, C. (2012). New Marxian Times! Reflections on the 4th ICTs and Society Conference "Critique, Democracy and Philosophy in 21st Century Information Society. Towards Critical Theories of Social Media". tripleC, 10(1), 114-121.

Fuchs, C., \& Mosco, V. (2012). Introduction: Marx is back-The importance of marxist theory and research for critical communication studies today. tripleC, 10(2), 127-140.

Galloway, A. R. (2004). Protocol: how control exists after decentralization. Massachusetts: MIT Press.

Gibson, J.J. (1977). The Theory of Affordances. In R. Shaw and J. Bransford (Eds.), Perceiving, Acting, and Knowing: Toward an Ecological Psychology (pp. 67-82). Lawrence Erlbaum.

Haggerty, K. (2006). Tear down the walls: on demolishing the panopticon. In D. Lyon (Ed.), Theorising surveillance: The panopticon and beyond (pp. 23-45). Portland: Willan Publishing.

Haggerty, K. D., \& Ericson, R. V. (2000). The surveillant assemblage. British Journal of Sociology, 51(4), 605-22.

Hier, S. P. (2002). Probing the surveillant assemblage: on the dialectics of surveillance practices as processes of social control. Surveillance \& Society, 1(3), 399-411.

Kaino, M. (2008). Bentham's concept of security in a global context: the pannomion and the public opinion tribunal as a universal plan. Journal of Bentham Studies, 10, 1-29.

Koops, B.-J. (2010). Law, technology, and shifting power relations. Berkley Technology Law Journal, 25(2), 973-1036.

Koskela, H. (2004). Webcams, TV shows and mobile phones: empowering exhibitionism. Surveillance and Society, 2(2/3), 199-215.

Koskela, H. (2011). 'Don’t mess with Texas!' Texas virtual border watch program and the (botched) politics of responsibilization. Crime Media Culture, 7(1), 49-65.

Latour, B. (1999). On recalling ANT. The Sociological Review, 47(1), 15-25.

Law, J. (1992). Notes on the theory of the actor-network: ordering, strategy and heterogeneity. Systems Practice, 5, 379-93.

Leroy, M.-L. (2002). Le panoptique inversé: Théorie du contrôle dans la pensée de Jeremy Bentham. In C. Lazzeri (Ed.), La production des institution (pp. 155-177). Besançon: Presses Universitaires FrancComtoises.

Lyon, D. (2001). Surveillance society: monitoring everyday life. Buckingham: Open University Press.

Lyon, D. (Ed.). (2003). Surveillance as social sorting: privacy, risk, and digital discrimination. London: Routledge.

Lyon, D. (2006). The search for surveillance theories. In D. Lyon (Ed.), Theorising surveillance: The panopticon and beyond (pp. 3-20). Portland: Willan Publishing.

Lyon, D. (2007). Surveillance studies: an overview. Cambridge: Polity.

Lyon, D. (2008). An electronic panopticon? A sociological critique of surveillance theory. The Sociological Review, 41(4), 653-678.

Mann, S. (2004). "Sousveillance": Inverse Surveillance in Multimedia Imaging. Computer Engineering, 620627. Available at: http://delivery.acm.org/10.1145/1030000/1027673/p620-mann.pdf?ip=137.56.133. 86\&id=1027673\&acc=ACTIVE\%20SERVICE \&key=0C390721DC3021FF.8E8A7FC83EB1C6A0. 4D4702B0C3E38B35.4D4702B0C3E38B35\&CFID $=596609361 \& C F T O K E N=89220847 \&$ acm _ = 1459527091_55c715c379b235850cfc211fe4d354da (accessed 01 April 2016).

Marwick, A. (2012). The public domain: surveillance in everyday life. Surveillance \& Society, 9(4), 378-393. 
Marx, G. T. (2002). What's new about the "New surveillance"? Classifying for change and continuity. Society, $1(1), 9-29$.

Mercer, D. (2010). CDC uses shopper-card data to trace salmonella. Bloomberg Business Week, 10 March.

Murakami Wood, D. (2007). Beyond the panopticon? Foucault and surveillance studies. In J. Crampton \& S. Elden (Eds.), Space, knowledge and power: Foucault and geography (pp. 245-263). Aldershot: Ashgate.

Murakami Wood, D. (2013). What is global surveillance? Towards a relational political economy of the global surveillant assemblage. Geoforum, 49, 317-326.

Pham, N., Ganti, R. K., Uddin, Y. S., Nath, S. \& Abdelzaher, T. (2010). Privacy-preserving reconstruction of multidimensional data maps in vehicular participatory sensing. WSN 2010: 7th European Conference on Wireless Sensor Networks.

Price, D.H. (2014). The New Surveillance Normal: NSA and Corporate Surveillance in the Age of Global Capitalism. Monthly Review, 66(3). Available at: http://monthlyreview.org/2014/07/01/the-newsurveillance-normal/. (accessed 04 April 2016).

Roessler, M. (2002). How to find hidden cameras. Available at: http://www.tentacle.franken.de/papers/ hiddencams.pdf (accessed 02 April 2016).

Romein, E., \& Schuilenburg, M. (2008). Are you on the fast track? The rise of surveillant assemblages in a post-industrial age. Architectural Theory Review, 13(3), 337-348.

Schofield, P. (2009). Bentham: a guide for the perplexed. London: Continuum.

Semple, J. (1987). Bentham's haunted house. The Bentham Newsletter, 11, 35-44.

Sunstein, C. R., \& Thaler, R. H. (2009). Nudge: improving decisions about health, wealth, and happiness. London: Penguin.

Taekke, J. (2011). Digital panopticism and organizational power. Surveillance \& Society, 8(4), 441-454.

Timan, T., \& Oudshoorn, N. (2012). Mobile cameras as new technologies of surveillance? How citizens experience the use of mobile cameras in public nightscapes. Surveillance \& Society, 10(2), 167-181.

Valverde, M. (2008). Police, sovereignty, and law: Foucaultian reflections. In M. Dubber \& M. Valverde (Eds.), Police and the liberal state (pp. 15-32). Stanford: Stanford Law Books.

van der Ploeg, I. (2003). Biometrics and the body as information: normative issues of the socio-technical coding of the body. In D. Lyon (Ed.), Surveillance as social sorting: Privacy, risk and digital discrimination (pp. 57-73). London: Routledge.

Varian, H. R. (2014). Beyond big data. Business Economics, 49(1), 27-31.

Whitaker, R. (1999). The end of privacy: how total surveillance is becoming a reality. New York: The New Press.

Zuboff, S. (2015). Big other: surveillance capitalism and the prospects of an information civilization. Journal of Information Technology, 30, 75-89.

Zuboff, S. (2016). The Secrets of Surveillance Capitalism. Frankfurter Allgemeine, Feuilleton. Available at: http://www.faz.net/aktuell/feuilleton/debatten/the-digital-debate/shoshana-zuboff-secrets-of-surveillancecapitalism-14103616.html (accessed 01 April 2016). 